\title{
Accumulation of Essential Mineral and Toxic Trace Elements in Crops and Soils of Vegetable Cropping Systems in Central Highlands of Sri Lanka
}

Lalith Suriyagoda ( $\square$ lalith.suriyagoda@gmail.com )

University of Peradeniya https://orcid.org/0000-0002-5253-2717

Ovini Dissanayake

National Institute of Fundamental Studies

Virashmi Kodithuwakku

University of Peradeniya

Isuri Maduwanthi

University of Peradeniya

Nuwandhya Dissanayaka

University of Peradeniya

Rohana Chandrajith

University of Peradeniya

\section{Research Article}

Keywords: Heavy metals, Leaching, Metalloids, Nutrition, Pollution

Posted Date: July 2nd, 2021

DOI: https://doi.org/10.21203/rs.3.rs-660623/v1

License: () (1) This work is licensed under a Creative Commons Attribution 4.0 International License.

Read Full License

Version of Record: A version of this preprint was published at The Journal of Agricultural Science on April 11th, 2022. See the published version at https://doi.org/10.1017/S0021859622000156. 


\section{Abstract}

Background and Aims Vegetables are widely cultivated in high rainfall and mountainous regions in Sri Lanka with poor soil conservation practices. Accumulation of essential mineral and toxic trace elements in these soils and widely cultivated vegetable crops are not known.

Methods One hundred soil and vegetable (i.e. cabbage, carrot and potato) samples were collected at the time of harvest and analysed for element concentrations.

Key Results Soils contained very high concentrations of essential mineral and toxic trace elements. When compare edible parts, cabbage contained the highest concentrations of mineral and toxic trace elements, and potato contained lowest. Irrespective of the crop, edible parts contained high concentrations of N, $\mathrm{P}$, $\mathrm{K},\left(14-35,2-6,15-24 \mathrm{~g} \mathrm{~kg}^{-1}\right.$, respectively), $\mathrm{Cu}, \mathrm{Zn}, \mathrm{Mn}$ (2.5-6.7, 11-30, 8-147 $\mathrm{mg} \mathrm{kg}^{-1}$, respectively). Vegetables also contained $\mathrm{As}, \mathrm{Cd}$ and $\mathrm{Pb}\left(0.04-1,0.02-0.15,0.02-0.26 \mathrm{mg} \mathrm{kg}^{-1}\right.$, respectively), but didn't exceed the maximum permissible limits. Irrespective of the crop $36-64 \mathrm{~kg} \mathrm{~N}, 6-11 \mathrm{~kg}$ of P, 35-45 kg K per ha were removed with the harvest. According to the current rate of vegetable consumption by a Sri Lankan adult (i.e. $240 \mathrm{~g} \mathrm{FW}$ per day), per capita consumption of 0.05-0.2 $\mathrm{mg} \mathrm{Cu}, 0.45-0.65 \mathrm{mg} \mathrm{Zn}$ and 0.5-2 $\mathrm{mg} \mathrm{Mn} \mathrm{day}^{-1}$ through these vegetables was observed, i.e. $5-23 \% \mathrm{Cu}, 7.5-11 \% \mathrm{Zn}$ and $22-87 \% \mathrm{Mn}$ of the recommended daily intake.

Conclusion Vegetables grown in the region served as a key source of essential mineral elements. However, agronomic mitigation strategies are needed to improve soil health and sustainability of these cropping systems.

\section{Introduction}

Crop productivity has increased over the past 50-60 years as a result of green revolution (Pingali 2012). With the development and use of high-yielding crop varieties, demand for fertilizers has also been increased. Therefore, farmers apply high doses of both organic and inorganic sources of nutrients aiming to reach higher crop productivities (Weerakkody and Mawalagedara 2020). However, continuous overdosing of fertilizers without following the recommendations has led to problems such as soil degradation, soil nutrient imbalances, nutrient toxicities to plants, and pollution of water bodies (Khai et al. 2007; Bandara et al. 2010; Weerakkody and Mawalagedara 2020). As a result, the sustainability of those agricultural systems has been threatened.

Intensive vegetable cultivation systems exhibit a significant contribution to the present vegetable production in Sri Lanka. Small-scale (i.e. less than 0.5 ha) farmer fields in Nuwara Eliya $\left(6.9497^{\circ} \mathrm{N}\right.$, 
$\left.80.7891^{\circ} \mathrm{E}\right)$ and Welimada $\left(6.9019^{\circ} \mathrm{N}, 80.9079^{\circ} \mathrm{E}\right)$ regions provide classic examples for commercial and intensive vegetable cultivation in open field conditions. High-value crops are grown, in rotation, three to four times per year without fallowing the land aiming to reach high income per unit of land and time (Sirisena and Suriyagoda 2018; Weerakkody and Mawalagedara 2020). Therefore, farmers mobilize all available and affordable inputs, including agrochemicals and manures, without considering the environment sustainability or profit margins (Sirisena and Suriyagoda 2018). Major vegetable crops cultivated in these regions include; carrot (Daucus carota L.), cabbage (Brassica oleracea L.), beetroot (Beta vulgaris L.), bean (Phaseolus vulgaris L.), leeks (Allium porrum L.) and potato (Solanum tuberosum L.).

Even though vegetables act as a key source of mineral elements its contribution to human nutrition is largely neglected in Asia (Ali and Tsou 1997; Weerakkody and Mawalagedara 2020). The quality of vegetable crops produced is influenced by the amount and type of mineral elements available in soil and the amount taken up by the crop. However, the nutritional quality of vegetables is not valued by these farmers. Therefore, they frequently apply inorganic sources of nitrogen $(N)$, phosphorus $(P)$ and potassium (K) to soil, and micro-nutrients such as zinc (Zn), sulfur (S), manganese (Mn), molybdenum (Mo), and copper $(\mathrm{Cu})$ through fertilizer mixers either to soil in the solid form or foliage in the liquid form. They also apply organic manures such as compost, cattle manure and poultry manure. As a result of this continuous practice, plant available $\mathrm{P}$ and $\mathrm{K}$ concentrations have reached sufficiency even for the succeeding crops (Wijewardana and Amarasiri 1997; Sirisena and Suriyagoda 2018). Moreover, the main watersheds in the country are situated around these vegetable cultivating regions, risking the pollution of a wide range of water sources (Diyabalanage et al. 2017; Sirisena and Suriyagoda 2017).

Micro-nutrients are essential dietary requirements for plants and animals. Daily intake/uptake of those are essential for the basic functioning of plants or animals (Abeywickrama et al. 2018). Deficiencies in micro-nutrients are known as "hidden hunger" as those deficiencies cannot be clinically identified till the last stages (Abeywickrama et al. 2018). Recent reviews suggested the prevalence of iron (Fe), Zn and calcium (Ca) deficiencies among Sri Lankans (Akhtar et al. 2013; Abeywickrama et al. 2018). Even though both macro- and micro-nutrients are frequently been applied to these intensive agricultural systems, the availability of those mineral elements in soils and accumulation in major vegetable crops grown are largely unknown (Ali and Tsou 1997; Weerakkody and Mawalagedara 2020). Moreover, according to the WHO/FAO recommendation, the per capita vegetable and fruit intake should be a minimum of $400 \mathrm{~g}$ or five servings per day to prevent the occurrence of chronic diseases

(Kanungsukkasem et al. 2009). However, in the year 2015 the per capita fruit and vegetable consumption in Sri Lanka was $240 \mathrm{~g}$ or three servings per day by an adult (Jayawardena et al. 2020). Therefore, it is important to study the contribution of major vegetables when supplying essential mineral elements to local communities.

It is reported that mineral fertilizers such as phosphates, and organic manures are sometimes contaminated with toxic trace elements such as arsenic (As), cadmium (Cd) and lead ( $\mathrm{Pb}$ ) (Dissanayake and Chandrajith 2009; Jayasumana et al. 2015; Mapa 2020). Continuous and excessive application of 
these mineral sources may result in increasing the bioavailability of those toxic trace elements in soil and accumulate in the food chain causing chronic health problems to humans (Premarathna et al. 2005; Dissanayake and Chandrajith 2009; Suriyagoda et al. 2018). However, the accumulation of these toxic trace elements in widely cultivated Sri Lankan vegetable crops has not been studied. Therefore, it is essential to study the concentrations of plant available forms of essential mineral elements and toxic trace elements in soil, accumulation in edible plant parts, and the amount removed by the crops with the harvest. Therefore, the objectives of this study were to evaluate the (i) concentrations of essential mineral and toxic trace elements in soils and crops, and (ii) amount removed with the harvest of widely cultivated vegetable crops from Nuwara Eliya and Welimada regions of Sri Lanka.

\section{Materials And Methods}

Vegetable crop and soil samples were collected from Nuwara Eliya and Welimada regions in Sri Lanka during the period from October to December 2019. Basic soil and climate characteristics of the two study regions are given in Table 1. Vegetable cultivation in these sloppy lands has been a major land use for decades. Temperature is optimal for the cultivation of most of the vegetable crops and receives a yearround abundant rainfall. Farmers also practice supplementary irrigation as required from natural waterways.

Table 1

Soil and climate characteristics in the two vegetable cultivating regions

\begin{tabular}{|lll|}
\hline Parameter & Nuwera Eliya & Welimada \\
\hline $\begin{array}{l}\text { Agro-climatic } \\
\text { zone }\end{array}$ & Up-country Wet zone & Up-country Intermediate zone \\
\hline $\begin{array}{l}\text { Main soil } \\
\text { types }\end{array}$ & $\begin{array}{l}\text { Red-yellow podzolic soils, wet mountain } \\
\text { regosols, and red-yellow podzolic soils with } \\
\text { prominent A1 horizon }\end{array}$ & $\begin{array}{l}\text { Reddish brown latasolic soils with } \\
\text { mountain regosols, and immature } \\
\text { brown loams }\end{array}$ \\
\hline $\begin{array}{l}\text { Topography } \\
\begin{array}{l}\text { Average } \\
\text { temperature }\end{array}\end{array}$ & Very steep, hilly and rolling & Mountainous, hilly and rolling \\
\hline $\begin{array}{l}\text { Annual rainfall } \\
\text { for the } 75 \% \\
\text { expectancy }\end{array}$ & 1800 mm - 3100 mm & $25^{\circ} \mathrm{C}$ \\
\hline $\begin{array}{l}\text { Major crops } \\
\text { Minor land }\end{array}$ & $\begin{array}{l}\text { tea, vegetables } \\
\text { paddy, perennial crops, natural forests, forest } \\
\text { plantations, scrub lands and grass lands }\end{array}$ & $\begin{array}{l}1400 \text { mm - 2400 mm } \\
\text { plantations and export agricultural } \\
\text { crops }\end{array}$ \\
\hline
\end{tabular}

Sources: General Soil Map, 1967; DOA, 2003 
Three widely grown vegetable crops in the region; cabbage, carrot and potato were selected for the study (AgStat 2018). The number of soil and plant samples to be collected from each region and crop was determined proportionately based on their extent (AgStat 2018). When collecting plant samples at least four sampling points from one field were selected considering the crop and topographical heterogeneities in the field. One square meter land area was selected for harvesting at each point. Harvested plants from those four points in a field were combined and mixed to make a composite sample. Both the above and below-ground plant parts of carrot and potato were harvested while only the shoots of cabbage were harvested from the base. Harvesting was done by pulling both carrot and potato plants after losing the soil around the base of the plant using a fork without damaging the below-ground plant parts by a skilled labourer. Cabbage plants were cut from the base using a harvesting knife to obtain the shoot. Fresh weights of shoots and roots harvested from each sample were recorded. Samples were collected on the days when farmers harvested their crops to be sent to markets. Therefore, eight visits were made to Nuwara Eliya and Welimada regions to collect those samples.

Soil samples were collected from the fields used to collect vegetable samples. When collecting soil samples at least four individual samples from the top $15 \mathrm{~cm}$ were collected. Samples from one field were combined and mixed to make a composite sample. Soil samples from nearby undisturbed forest patches, representing unfertilized native vegetation in the region, were also collected. One hundred soil and vegetable samples from intensively vegetable cultivated fields, and nine soil samples from forest patches were collected (Table 2). Soil samples were collected at the time of plant sample collection, and also within the quadrat of plant samples collected.

Table 2

Description of the soil and plant (only from crop fields) samples collected

\begin{tabular}{|llllll|}
\hline District & \multicolumn{2}{l}{ Crop fields } & \multicolumn{3}{c|}{ Forest patches } \\
\cline { 2 - 4 } & Carrot & Cabbage & Potato & Total \\
\hline Nuwara Eliya & 36 & 17 & 9 & 6 & 68 \\
\hline Welimada & 10 & 4 & 24 & 3 & 41 \\
\hline Total & 46 & 21 & 33 & 9 & 109 \\
\hline
\end{tabular}

Both soil and plant samples were transported to the Department of Crop Science, Faculty of Agriculture, University of Peradeniya for processing and laboratory analyses. Apart from the soil and vegetable samples, compost, cattle manure and poultry manure samples were also collected from farmer fields or retail traders in the region to measure nutrient concentration in those samples.

Soil samples were air-dried and sieved through one $\mathrm{mm}$ sieve before estimating mineral element and toxic trace element concentrations. Total $\mathrm{N}$ concentration was estimated using the Kjeldahl method (Anderson and Ingram 1993). Ammonium acetate-extractable $\mathrm{K}$ was extracted with a $1 \mathrm{M}$ ammonium acetate $\left(\mathrm{NH}_{4} \mathrm{OAc}\right)$ solution buffered to $\mathrm{pH} 7$ and testing in a flame atomic absorption spectrophotometer 
(GBC model 932AA, Hampshire, USA) (Van Ranst et al. 1999). Available P concentration was measured using Olsen method (Olsen et al. 1954). Soil solution concentrations of N, P and K were measured using the column displacement procedure (Adams et al. 1980; Somaweera et al. 2017). Organic matter, pH (1:5 ratio of soil: water) and EC of the soil samples were also measured (Anderson and Ingram 1993). Plant available concentrations of other mineral elements (i.e. $\mathrm{Ca}, \mathrm{Mg}, \mathrm{Mo}, \mathrm{Cu}, \mathrm{Mn}, \mathrm{Fe}, \mathrm{Ni}$ and $\mathrm{Zn}$ ) and toxic trace elements (i.e. As, $\mathrm{Pb}$ and $\mathrm{Cd}$ ) in soil samples were determined after extracting in $0.01 \mathrm{M} \mathrm{CaCl}_{2}$ solution. For this, approximately $4 \mathrm{~g}$ of air-dried, sieved and homogenised soil sample was weighed into $60 \mathrm{~mL}$ centrifuge tube, filled with $40 \mathrm{~mL}$ of $0.01 \mathrm{M} \mathrm{CaCl}_{2}$, centrifuged at a $130 \mathrm{rpm}$ in an end-to-end shaker for two hours (Houba et al. 2000). Thereafter, those tubes were centrifuged at 3,600 rpm for four minutes and the supernatant was filtered through a cellulose acetate syringe filter with a pore size of $0.45 \mu \mathrm{m}$. The supernatant was diluted seven times using deionized water and element concentrations were determined using ICP-MS (Thermo iCapQ, Bremen, Germany).

To determine the dry weight (i.e. moisture content) and element concentrations (macro- and micronutrients, and toxic trace elements) in plant samples, a representative sub sample with a minimum of 500 $\mathrm{g}$ fresh weight from each sample was prepared. The fresh weight of the sample was obtained and ovendried until a constant weight was reached (i.e. minimum of four days) at $70^{\circ} \mathrm{C}$. For this root and shoot samples of carrot and potato, and shoot samples of cabbage were used. The difference between fresh and dry weight was considered as the moisture content and expressed as a percentage of fresh weight. Oven-dried samples were ground to make a powder using a steel ball mill and stored in the oven at $60^{\circ} \mathrm{C}$. Care was taken to clean the equipment after processing of each sample. An approximately $100 \mathrm{mg}$ subsample was taken and digested in nitric-perchloric mix acid and analyzed using the vanado-molybdophosphate yellow colorimetric method for the determination of tissue P concentration. Tissue $\mathrm{K}$ concentration was determined as explained by Van Ranst et al. (1999) and N concentration using Kjeldahl method (Anderson and Ingram 1993). For the determination of other elements in plant tissues (i.e. $\mathrm{Cu}, \mathrm{Zn}, \mathrm{Mn}, \mathrm{As}, \mathrm{Cd}$ and $\mathrm{Pb}$ ), approximately $200 \mathrm{mg}$ subsample was digested in $2 \mathrm{~mL}$ hydrogen peroxide/ $4 \mathrm{~mL}$ nitric acid $\left(160^{\circ} \mathrm{C}\right.$ for 40 minutes) using Milestone microwave digestion system (EthosEASY, Sorisole (BG), Italy). All the chemicals used were analytical grade. Plant tissue elemental concentrations were quantified using ICP-MS method. Regent blanks, in-house standard sample (Bg450) and an international reference material, IRMM-804 (Institute for Reference Materials and Measurements (IRMM), Geel, Belgium) were used for analytical quality control. This allowed the comparison of data within and among digestion cycles. While collecting soil and plant samples farmers were interviewed by filling a short-structured questionnaire to understand their current fertilizer application plan.

Concentrations of mineral and toxic trace elements, moisture content, and fresh weights of cabbage shoots, potato tubers and carrot roots were used when estimating the removal of mineral and toxic trace elements with harvest.

Data were analysed using SAS statistical software (SAS 2005) as a factorial ANOVA to study the effects of regions (i.e. Nuwara Eliya and Welimada), crops (i.e. cabbage, carrot, and potato) and their interactions on tested variables. All the interpretations were made at a significance level of $a=0.05$. 


\section{Results}

Types of fertilisers applied

Majority of vegetable farmers used both inorganic and organic fertilisers (Table 3). Out of the farmers who used inorganic fertilizers, majority preferred mixed fertilizers than straight fertilizers. Farmers used different types of organic manures simultaneously with inorganic fertilizers. Application of compost and poultry manure was more common than applying either cattle manure or charcoal. The number of farmers who applied lime or dolomite was lower, and none of the farmers have applied green manure or crop residues.

Table 3

Types of fertilizers applied by vegetable farmers in Nuwara Eliya and Welimada regions $(\mathrm{n}=94)$

\begin{tabular}{|ll|}
\hline Fertilizer type & Percentage of farmers used the practice (\%) \\
\hline Inorganic fertilizers & 81.1 \\
\hline i. Mixed fertilizers & 79.7 \\
\hline ii. Straight fertilizers & 32.4 \\
\hline Organic manures & 64.9 \\
\hline i. Compost & 39.2 \\
\hline ii. Poultry manure & 32.4 \\
\hline iii. Cattle manure & 24.3 \\
\hline iv. Charcoal & 20.3 \\
\hline v. Lime/dolomite & 6.8 \\
\hline vi. Green manure/crop residue & 0 \\
\hline
\end{tabular}

Concentration of mineral elements in soils and manures

Irrespective of the crops grown, soils in Nuwara Eliya contained 2.2, 1.4 and 2.6-times higher concentrations of total $\mathrm{N}$, available $\mathrm{P}$ and organic matter, respectively than that observed in Welimada region (Fig. 1). Fields used to cultivate carrot and potato in Nuwara Eliya contained higher exchangeable $\mathrm{K}$ concentrations than those crop fields in Welimada. The highest EC value was observed in potato fields in Welimada. Concentrations of $\mathrm{P}$ and $\mathrm{K}$ reported in crop fields were higher than the levels required for optimal growth of crops. Plant available P, exchangeable K and EC values reported in crop fields were 18, 6.7 and 3.4-times higher, respectively while $\mathrm{N}, \mathrm{pH}$ and organic matter levels were comparable to those observed in forest soils. Soil solution concentrations of $\mathrm{N}, \mathrm{P}$ and $\mathrm{K}$ were higher than those reported in forest soils (Fig. 2). 
The concentration of $\mathrm{CaCl}_{2}$ extracted mineral elements in soil between the two cultivating regions and crop fields were similar except for the higher $\mathrm{Mg}$ and lower Mn concentrations in Welimada region than those observed in Nuwara Eliya (Table 4). Moreover, a higher $\mathrm{Cu}$ concentration was reported in potato fields in Nuwara Eliya and carrot fields in Welimada than other crop fields in those regions.

Table 4

Micro nutrient concentrations ( $\mathrm{mg} \mathrm{kg}-1$ ) in the soils of two cultivating regions when extracted using 0.01 $\mathrm{M} \mathrm{CaCl} 2$, mean $\pm \mathrm{SE}$, sample size is as stated in Table 2

\begin{tabular}{|c|c|c|c|c|c|c|c|c|c|}
\hline Region & Crop & $\begin{array}{l}\mathrm{Ca} \\
\mathrm{mg} \mathrm{g}_{1}^{-}\end{array}$ & $\begin{array}{l}\mathrm{Mg} \\
\mathrm{mg} \\
\mathrm{kg}^{-1}\end{array}$ & $\begin{array}{l}\mathrm{Mn} \\
\mathrm{mg} \\
\mathrm{kg}^{-1}\end{array}$ & $\begin{array}{l}\mathrm{Fe} \\
\mathrm{mg} \\
\mathrm{kg}^{-1}\end{array}$ & $\begin{array}{l}\mathrm{Ni} \\
\mathrm{mg} \\
\mathrm{kg}^{-1}\end{array}$ & $\begin{array}{l}\mathrm{Zn} \\
\mathrm{mg} \\
\mathrm{kg}^{-1}\end{array}$ & $\begin{array}{l}\text { Mo } \\
\mu \mathrm{g} \\
\mathrm{kg}^{-1}\end{array}$ & $\begin{array}{l}\mathrm{Cu} \\
\mu \mathrm{g} \mathrm{kg}\end{array}$ \\
\hline \multirow[t]{3}{*}{$\begin{array}{l}\text { Nuwara } \\
\text { Eliya }\end{array}$} & Cabbage & $\begin{array}{l}3.1 \pm \\
0.94\end{array}$ & $\begin{array}{l}183 \pm \\
24\end{array}$ & $\begin{array}{l}48 \pm \\
13\end{array}$ & $\begin{array}{l}2.1 \pm \\
0.42\end{array}$ & $\begin{array}{l}5.7 \pm \\
0.2\end{array}$ & $\begin{array}{l}0.8 \pm \\
0.1\end{array}$ & $\begin{array}{l}29 \pm \\
2\end{array}$ & $\begin{array}{l}248 \pm \\
96\end{array}$ \\
\hline & Carrot & $\begin{array}{l}3.9 \pm \\
0.49\end{array}$ & $\begin{array}{l}158 \pm \\
15\end{array}$ & $33 \pm 8$ & $\begin{array}{l}2.1 \pm \\
0.22\end{array}$ & $\begin{array}{l}5.6 \pm \\
0.1\end{array}$ & $\begin{array}{l}1.1 \pm \\
0.3\end{array}$ & $\begin{array}{l}37 \pm \\
12\end{array}$ & $\begin{array}{l}144 \pm \\
17\end{array}$ \\
\hline & Potato & $\begin{array}{l}3.7 \pm \\
0.85\end{array}$ & $\begin{array}{l}175 \pm \\
10\end{array}$ & $\begin{array}{l}45 \pm \\
10\end{array}$ & $\begin{array}{l}2.3 \pm \\
0.12\end{array}$ & $\begin{array}{l}6.0 \pm \\
0.2\end{array}$ & $\begin{array}{l}1.4 \pm \\
0.4\end{array}$ & $\begin{array}{l}30 \pm \\
3\end{array}$ & $\begin{array}{l}718 \pm \\
86\end{array}$ \\
\hline \multirow[t]{3}{*}{ Welimada } & Cabbage & $\begin{array}{l}3.3 \pm \\
0.56\end{array}$ & $\begin{array}{l}226 \pm \\
16\end{array}$ & $29 \pm 9$ & $\begin{array}{l}2.4 \pm \\
0.08\end{array}$ & $\begin{array}{l}5.9 \pm \\
0.1\end{array}$ & $\begin{array}{l}1.3 \pm \\
0.3\end{array}$ & $\begin{array}{l}31 \pm \\
2\end{array}$ & $\begin{array}{l}480 \pm \\
117\end{array}$ \\
\hline & Carrot & $\begin{array}{l}3.8 \pm \\
0.39\end{array}$ & $\begin{array}{l}224 \pm \\
10\end{array}$ & $19 \pm 3$ & $\begin{array}{l}2.3 \pm \\
0.03\end{array}$ & $\begin{array}{l}6.1 \pm \\
0.1\end{array}$ & $\begin{array}{l}1.2 \pm \\
0.2\end{array}$ & $\begin{array}{l}31 \pm \\
1\end{array}$ & $\begin{array}{l}728 \pm \\
86\end{array}$ \\
\hline & Potato & $\begin{array}{l}3.4 \pm \\
0.56\end{array}$ & $\begin{array}{l}194 \pm \\
14\end{array}$ & $28 \pm 9$ & $\begin{array}{l}2.2 \pm \\
0.17\end{array}$ & $\begin{array}{l}5.7 \pm \\
0.1\end{array}$ & $\begin{array}{l}1.0 \pm \\
0.3\end{array}$ & $\begin{array}{l}40 \pm \\
2\end{array}$ & $\begin{array}{l}148 \pm \\
17\end{array}$ \\
\hline
\end{tabular}

Soils in both regions and crop fields contained high concentrations of $\mathrm{CaCl}_{2}$ extracted $\mathrm{As}, \mathrm{Cd}$ and $\mathrm{Pb}$ (Fig. 3). Concentrations of $\mathrm{Pb}$ and $\mathrm{Cd}$ between the two regions and crop fields were similar, except for the lower concentration of $\mathrm{Pb}$ reported in the cabbage fields in Welimada. Moreover, a relatively lower concentration of As was reported in Nuwara Eliya soils than that reported in Welimada.

Cattle manure contained a higher concentration of $\mathrm{Mg}, \mathrm{Zn}$ and $\mathrm{Pb}$ while poultry manure contained higher concentrations of Mo, As and Cd than other sources of organic manure (Table 5). The concentration of elements in cattle manure varied widely than that observed in poultry manure and compost. Compost contained the lowest concentrations of $\mathrm{Zn}, \mathrm{Cu}, \mathrm{Mo}$, As and $\mathrm{Cd}$ than those in cattle manure and poultry manure. 
Table 5

Element concentration in the organic matter applied when extracted using $0.01 \mathrm{M} \mathrm{CaCl} 2$, (mean $\pm \mathrm{SE}, \mathrm{n}=6$ )

\begin{tabular}{|llll|}
\hline Element & Cattle manure & Compost & Poultry manure \\
\hline $\mathrm{N}-\mathrm{mg} \mathrm{g}^{-1}$ & $13.7 \pm 1.5$ & $12.3 \pm 0.9$ & $33.8 \pm 1.8$ \\
\hline $\mathrm{P}-\mathrm{mg} \mathrm{g}^{-1}$ & $5.1 \pm 0.9$ & $4.2 \pm 0.5$ & $24.3 \pm 1.5$ \\
\hline $\mathrm{K}-\mathrm{mg} \mathrm{g}^{-1}$ & $3.4 \pm 1.3$ & $3.7 \pm 0.8$ & $17.6 \pm 3.5$ \\
\hline $\mathrm{Ca}-\mathrm{mg} \mathrm{g}^{-1}$ & $2.9 \pm 0.92$ & $3.7 \pm 0.36$ & $1.5 \pm 0.19$ \\
\hline $\mathrm{Mg}-\mathrm{mg} \mathrm{kg}^{-1}$ & $500 \pm 181$ & $273 \pm 39$ & $258 \pm 12$ \\
\hline $\mathrm{Mn}-\mathrm{mg} \mathrm{kg}^{-1}$ & $30 \pm 24$ & $14 \pm 5.7$ & $5.7 \pm 0.3$ \\
\hline $\mathrm{Fe}-\mathrm{mg} \mathrm{kg}^{-1}$ & $3.6 \pm 1.8$ & $2.9 \pm 0.33$ & $1.9 \pm 0.01$ \\
\hline $\mathrm{Ni}-\mathrm{mg} \mathrm{kg}^{-1}$ & $4.9 \pm 1.9$ & $5.8 \pm 0.6$ & $2.1 \pm 0.1$ \\
\hline $\mathrm{Zn}-\mathrm{mg} \mathrm{kg}^{-1}$ & $10.7 \pm 8.6$ & $1.3 \pm 0.35$ & $5.2 \pm 0.2$ \\
\hline $\mathrm{Cu}-\mathrm{mg} \mathrm{kg}^{-1}$ & $2.7 \pm 1.5$ & $0.6 \pm 0.02$ & $1.7 \pm 0.11$ \\
\hline $\mathrm{Mo}-\mathrm{gg} \mathrm{kg}^{-1}$ & $209 \pm 89$ & $64 \pm 9$ & $598 \pm 35$ \\
\hline As- $\mu \mathrm{g} \mathrm{kg}^{-1}$ & $111 \pm 27$ & $58 \pm 19$ & $274 \pm 17$ \\
\hline $\mathrm{Cd}-\mu \mathrm{g} \mathrm{kg}^{-1}$ & $35 \pm 11$ & $10 \pm 3$ & $62 \pm 4$ \\
\hline $\mathrm{Pb}-\mu \mathrm{g} \mathrm{kg}^{-1}$ & $207 \pm 176$ & $120 \pm 60$ & $35 \pm 2.4$ \\
\hline
\end{tabular}

Yield and dry matter content

The harvested fresh weights of cabbage, carrot roots and potato tubers were $2.6 \pm 0.3,2.2 \pm 0.7$ and $1.7 \pm$ $0.5 \mathrm{~kg} \mathrm{~m}^{-2}$, respectively and those were similar between the two regions. Dry matter content of the shoot samples of cabbage, carrot and potato were $7.5,12$ and $16.5 \%$, respectively while that of carrot roots and potato tubers were 9 and $13.9 \%$, respectively.

Concentration of mineral elements in shoots and roots

Nitrogen concentration in both roots and shoots of the three crops was similar between the two cultivating regions (Fig. 4). Carrot and potato shoots had higher $\mathrm{N}$ concentrations than that in their roots. When compare crops, cabbage recorded the highest shoot $\mathrm{N}$ concentration in both regions. Nitrogen concentration in carrot roots was higher than that in potato tubers in Nuwara Eliya while it was similar 
between the two crops in Welimada. When compare edible parts, cabbage shoots contained 1.8 and 2.1times higher $\mathrm{N}$ concentrations than in carrot roots and potato tubers, respectively.

Crops grown in Welimada had a higher shoot and root concentrations of $\mathrm{P}$ than that in Nuwara Eliya (Fig. 4). When compare crops, shoot $\mathrm{P}$ concentration was the highest in cabbage while that in potato shoots was the lowest in both the regions. Carrot roots contained more $\mathrm{P}$ than in potato tubers in both regions. When compare edible parts, cabbage shoots contained 1.7 and 2.2-times higher concentrations of $P$ than in carrot roots and potato tubers, respectively.

Shoot K concentration of the three crops was higher in Nuwara Eliya than that in Welimada while root K concentration between the two regions was similar (Fig. 4). Potato shoots had the highest $\mathrm{K}$ concentration while in cabbage shoots was the lowest in both regions. Carrot roots contained more $\mathrm{K}$ than in potato tubers. When compare edible parts, carrot roots contained 1.2 and 1.5-times higher concentration of $\mathrm{K}$ than in cabbage shoots and potato tubers, respectively.

Apart from higher N, P and $\mathrm{K}$, shoots of carrot and potato contained higher concentrations of $\mathrm{Cu}, \mathrm{Mn}$ and $\mathrm{Zn}$ than that in their roots or tubers (Table 6). Among shoots, cabbage contained the lowest concentrations of $\mathrm{Mn}, \mathrm{Cu}$ and $\mathrm{Zn}$ while potato contained the highest concentrations of those elements. When compare edible parts, cabbage shoots contained higher concentrations of all the tested micronutrients than that in carrot roots and potato tubers (Table 6).

Table 6

Micro nutrient concentrations ( $\mathrm{mg} \mathrm{kg}-1)$ in the shoots and roots of three crops from two cultivating regions, mean $\pm \mathrm{SE}$, sample size is as stated in Table 2

\begin{tabular}{|llllll|}
\hline Region & Crop & Plant part & Cu & Mn & Zn \\
\hline Nuwara Eliya & Cabbage & Shoot & $3.3 \pm 0.58$ & $57 \pm 5.3$ & $30 \pm 5.8$ \\
\cline { 3 - 6 } & Carrot & Shoot & $10.0 \pm 0.58$ & $195 \pm 22$ & $37 \pm 4.1$ \\
& & Root & $6.7 \pm 0.33$ & $41 \pm 4.6$ & $25 \pm 2.1$ \\
\hline \multirow{2}{*}{ Welimada } & Potato & Shoot & $15.8 \pm 1.20$ & $529 \pm 193$ & $153 \pm 7.1$ \\
\hline & & Tuber & $4.2 \pm 0.42$ & $8 \pm 2.8$ & $11 \pm 2.8$ \\
\hline & Carrot & Shoot & $5.8 \pm 0.50$ & $383 \pm 107$ & $50 \pm 12.6$ \\
& & Root & $5.8 \pm 0.67$ & $57 \pm 13$ & $21 \pm 2.9$ \\
\hline & Potato & Shoot & $16.6 \pm 1.25$ & $904 \pm 95$ & $110 \pm 9.3$ \\
\hline & & Tuber & $6.7 \pm 0.33$ & $24 \pm 3.3$ & $14 \pm 1.5$ \\
\hline
\end{tabular}

Concentration of toxic trace elements in shoots and roots 
Irrespective of the region, carrot and potato shoots contained higher concentrations of $\mathrm{As}, \mathrm{Cd}$ and $\mathrm{Pb}$ than those in their roots/tubers (Fig. 5). The concentration of $\mathrm{Pb}$ in potato shoots was higher than the other two crops in Welimada, while that in Nuwara Eliya was similar. The lowest and highest shoot Cd concentrations were recorded in cabbage and potato, respectively. The concentration of As in carrot shoots was lower than that in cabbage and potato shoots. When compare edible parts, cabbage shoots contained the highest concentrations of $\mathrm{As}, \mathrm{Cd}$ and $\mathrm{Pb}$ i.e. 6 and 27-times higher concentration of As, 1.2 and 1.8-times higher concentration of $\mathrm{Cd}$, and 16 and 3-times higher concentration of $\mathrm{Pb}$ than that in carrot roots and potato tubers, respectively.

Irrespective of the crop, the mean quantity of mineral and toxic trace elements contained in $240 \mathrm{~g}$ of fresh edible parts of the three crops were $0.4-0.6 \mathrm{~g} \mathrm{~N}, 0.06-0.1 \mathrm{~g}$ of $\mathrm{P}, 0.3-0.5 \mathrm{~g} \mathrm{~K}, 0.05-0.2 \mathrm{mg} \mathrm{Cu}, 0.5-2 \mathrm{mg}$ $\mathrm{Mn}$ and $0.45-0.65 \mathrm{mg} \mathrm{Zn}$ (Fig. 6). Additionally, 0.001-0.02 mg As, $0.001-0.002 \mathrm{mg} \mathrm{Cd}, 0.0004-0.003$ $\mathrm{mg} \mathrm{Pb}$ were also contained in $240 \mathrm{~g} \mathrm{FW}$ of those vegetables. The amount of mineral and toxic trace elements removed with the harvest from one ha land also had a similar pattern, i.e. $36-64 \mathrm{~kg} \mathrm{~N}, 6-11 \mathrm{~kg}$ of P, 35-45 kg K, 6-13 g Cu, 37-199 g Mn, 44-53 g Zn, 0.1-1.9 g As, 0.12-0.18 g Cd and 0.04-0.32 g $\mathrm{Pb}$ per ha were removed (Fig. 6).

\section{Discussion}

Soils were heavily fertilized and rich in minerals and toxic trace elements

Vegetable fields in both Nuwara Eliya and Welimada regions of Sri Lanka have frequently and heavily been fertilized using both inorganic and organic sources of nutrients for decades (Dissanayake and Chandrajith 2009; Sirisena and Suriyagoda 2018; Dandeniya and Caucci 2020). Therefore, soil fertility levels have been built up to very high levels (i.e. to the levels higher than that required for optimal plant growth), e.g., organic matter, N, P and K concentrations and EC levels were very high. As far as authors are aware this much higher available $\mathrm{P}$ and exchangeable $\mathrm{K}$ concentrations have not been previously reported from any agricultural fields. This situation has caused soil solution to retain very high concentrations of $\mathrm{N}, \mathrm{P}$ and $\mathrm{K}$ as observed in the leaching column experiment.

Apart from the application of straight fertilizers such as urea $(N)$, triple superphosphate $(P)$ and muriate of potash $(K)$, the use of organic matter and inorganic fertilizer mixtures available in the market has resulted in the development of micronutrient levels, and inevitably, the toxic trace element concentrations due to their poor quality (Tables 3,4,5) (Premarathna et al. 2005; Dissanayake and Chandrajith 2009; Bandara et al. 2010; Jayasumana et al. 2015). The concentrations of micro nutrients and toxic trace elements made available to crops through the application of organic matter varied depending on the type of organic matter applied and region, e.g., the organic matter added to soil in this region contained a lower concentration of As than that reported in rice cultivating regions of Sri Lanka (Jayasumana et al. 2015). Moreover, the same authors reported that the inorganic fertilizers contained a higher concentration of toxic trace elements than those found in organic matter. Despite these heterogeneities, due to the continuous application of fertilizers and manures concentrations of micronutrients and toxic trace 
elements have been built up to very high levels. Similar to the findings of this experiment, the presence of high micronutrient and toxic trace element concentrations in the soils from the same region and intensively cultivated cropping fields in North China have previously been reported (Premarathna et al. 2005; Ju et al. 2007).

Farmers in these vegetable cultivated fields have not adopted adequate soil conservation practices despite located in mountainous areas exposed to heavy rainfall (Samarakoon and Abeygunawardena 1996; Diyabalanage et al. 2017; Weerakkody and Mawalagedara 2020). It is also reported that the disturbed and damaged soil structures with high organic matter content can no longer be protected by microbial decomposition and aggregation (Kobierski et al. 2020). These conditions have aggravated the risk in erosion and leaching, polluting aquatic ecosystems downstream which are important tributaries and reservoirs in Sri Lanka (Samarakoon and Abeygunawardena 1996; Bandara et al. 2010; Diyabalanage et al. 2017; Sirisena and Suriyagoda 2018). This highlights the importance of revising (e.g., cutting down) fertilizer application plans and adopting soil conservation methods urgently in this region.

Soils in the region were rich in organic matter, particularly at Nuwara Eliya. The addition of organic matter is the cause of the development of high organic matter content in agricultural soils while the senesced biomass contributed to the accumulation of organic matter in natural forests. Application of poultry manure and cattle manure has become popular among vegetable farmers in this region as it increases productivity than applying inorganic fertilizers alone (Table 2) (Wijewardena and Amarasiri 1997; Wijewardena 2000). Greater accumulation of organic matter in Nuwara Eliya than that in Welimada would also be due to the cooler temperatures in Nuwara Eliya slowing down the decomposition of organic matter and mineralization (Table 1). Moreover, as farmers practice crop rotation in their fields, a significant difference in mineral element concentrations among fields within a region was not observed. As a result, irrespective of the crop grown, Nuwara Eliya soils retained more organic matter than that in Welimada.

Vegetables as a source of essential mineral elements

Among the edible parts of the crops studied, element concentrations were the highest in cabbage and lowest in potato. Similar pattern was observed in the amounts of mineral and toxic trace elements removed with the harvest from one ha land, except for $\mathrm{K}$ and $\mathrm{Cu}$. However, the amounts of mineral element intake through these crops in a daily ration (i.e. $240 \mathrm{~g} \mathrm{FW}$ ) did not follow the same pattern due to the difference in their dry matter content (i.e. cabbage < carrot < potato) (Fig. 6).

Even though these soils have been heavily fertilized, only some of the essential mineral elements showed high concentrations in plant tissues such as $\mathrm{P}$ and $\mathrm{K}$. Moreover, none of the crops displayed deficiency or toxicity symptoms of mineral elements. Therefore, vegetables produced in this region can be considered as a major source of mineral elements to the local community and used to minimize mineral malnutrition (i.e. hidden hunger). However, people suffering from chronic disorders such as kidney disease may reduce the consumption of vegetables such as cabbage and carrot produced in this region as those vegetables contain high concentrations of $\mathrm{P}$ and $\mathrm{K}$ (Parpia et al. 2018). 
When compare mineral accumulation, $\mathrm{N}$ concentration in green leaves of a range of vegetables from different parts of the country was lower than that reported in the present study (Liyanage et al. 2000). Similarly, potatoes produced in Canada and the Czech Republic, and cabbage produced in Turkey also contained lower concentrations of essential mineral elements in their edible parts and in the soil solution than reported in this experiment (Kiziloglu et al. 2008; Bártová et al. 2013; Liang et al. 2019). However, Takahashi et al. (2018) and Wen et al. (2019) reported similar concentrations of N, P and K in cabbage and lettuce tissues when grown in soils well fertilized with N,P and K. Therefore, higher tissue N, P and K concentrations reported in the crops grown in this region would also be due to heavy $\mathrm{N}, \mathrm{P}$ and $\mathrm{K}$ fertilization.

Vegetables act as a key source of micronutrients in the human diet. Mineral elements such as $\mathrm{Zn}, \mathrm{Mn}$ and $\mathrm{Cu}$ are either components in the large number of enzymes or essential for enzymatic reactions in both plants and animals (Abeywickrama et al. 2018). According to the current rate of vegetable consumption by a Sri Lankan adult (i.e. $240 \mathrm{~g}$ per day), per capita consumption of $0.05-0.2 \mathrm{mg} \mathrm{Cu}, 0.45-0.65 \mathrm{mg} \mathrm{Zn}$ and $0.5-2 \mathrm{mg} \mathrm{Mn} \mathrm{day}^{-1}$ through these vegetables was observed. These amounts represent only $5-23 \%$ $\mathrm{Cu}, 7.5-11 \% \mathrm{Zn}$ and $22-87 \% \mathrm{Mn}$ of the recommended daily intake (IMNA 2001), and thus, these vegetables contributed as a key source of mineral elements requirement to the local community. It is reported that the residents of almost all South Asian countries consume extremely low quantities of fruit and vegetables, lower than the World Health Organization recommendation (Dizon et al. 2019; Jayawardena et al. 2020). Therefore, in terms of quantity, vegetable consumption has to be increased, particularly for vegetable-based diets to increase the provision of a mineral element through vegetables. Moreover, the identification of vegetables rich in minerals and methods that can be used to enrich/fortify vegetables with minerals need to be investigated (Dobosy et al. 2020).

Carrot and potato shoots contained high concentrations of mineral elements and toxic trace elements than those present in their roots/tubers, and higher than those present in cabbage shoots. Despite nutritional excellence, carrot and potato shoots are not generally consumed as vegetables but used in making compost. Even though the chance of contaminating with toxic trace elements is lower in shoots than that in roots or tubers (Setiyo et al. 2020), an opposite response was observed in the present study. As samples were carefully washed using running water before drying for element analysis, the observed concentration of mineral elements would have not been due to surface accumulation, but represent the amount accumulated in leaf tissues. This could be due to the heavy use of foliar fertilizers and pesticides for these crops in this region (Shahid et al. 2017). However, this needs further testing and confirmation.

Although mineral elements are essential, excessive and long-term intake, higher than the required amount may cause complications e.g., long-term intake of $\mathrm{Zn}$ higher than the recommended level would cause problems in the metabolism of $\mathrm{Cu}$ (FAO/WHO 2001).

However, according to the findings of this study the available concentrations of essential mineral elements would not cause a serious threat to its consumers as the tissue concentrations have not been built up to toxic levels, but would cause detrimental impacts to the environment. Therefore, it is important 
to reduce the rate of fertilizer application, implement soil conservation methods, educate farmers on good agricultural practices (GAP), avoid the flow of agricultural residues and wastewater directly to natural waterways to minimize environmental pollution and increase the health, safety and wellbeing of these vegetable growers and consumers (Weerakkody and Mawalagedara 2020). In this process, evaluation and monitoring of nutrient levels in soils and vegetables and implementation of policy and regular measures by the responsible organizations is required.

Accumulation of toxic trace elements in vegetables

According to the FAO/WHO (2019) guidelines established for human consumption, the maximum permissible limit of $\mathrm{Pb}$ in Brassica vegetables, and root and tuber crops is $0.1 \mathrm{mg} \mathrm{kg}^{-1}$. Similarly, the maximum permissible limit of $\mathrm{Cd}$ in Brassica vegetables is $0.05 \mathrm{mg} \mathrm{kg}^{-1}$, and in root and tuber crops is $0.1 \mathrm{mg} \mathrm{kg}^{-1}$. European Commission (EU 2006) has set the permissible levels of $\mathrm{Cd}$ and $\mathrm{Pb}$ in potato tubers as 0.05 and $0.1 \mathrm{mg} \mathrm{kg}^{-1}$, respectively. Moreover, the maximum permissible levels of $\mathrm{Cd}, \mathrm{Pb}$ and $\mathrm{As}$ set for leafy vegetables and root crops in China are $0.05,0.1$ and $0.5 \mathrm{mg} \mathrm{kg}^{-1}$, respectively (GAIN 2014). All the above limits have been given on a fresh weight basis. When comparing those limits with the values observed in the present experiment (i.e. concentration of toxic trace elements in dry weight basis $x$ dry matter content/100), the concentrations of $\mathrm{As}, \mathrm{Cd}$ and $\mathrm{Pb}$ observed in edible parts of these crops on fresh weight basis did not exceed the maximum permissible limits established. However, Premerathna et al. (2005) reported the presence of high $\mathrm{Cd}$ in cabbage shoots from the same region exceeding maximum permissible limits. Similarly, the leafy vegetable Mukunuwenna (Alternanthera sessilis L.) samples collected from different urban regions in Sri Lanka also contained similar or higher concentrations of Cd and $\mathrm{Pb}$ than observed in the present study (Kananke et al. 2014, 2016). It is also reported that irrigation of agricultural lands with wastewater leads to the accumulation of toxic trace elements in soils and crops grown (Kiziloglu et al. 2008; Sharma et al. 2016). Therefore, the concentration of toxic trace elements in vegetable crops depend on the variation in soil characteristics such as soil $\mathrm{pH}$, clay and organic matter contents, crop management practices such as quality of irrigation water and fertilizer applied, and crop adaptations (Tack, 2014; Khan et al. 2015; Setiyo et al. 2020). It is also suggested that $P$ fertilizers induced immobilization of heavy metals such as Pb, Cd, and Zn in soil (Wang et al. 2008; Yang et al. 2019) and decrease translocation from roots to shoots in cabbage (Qiu et al. 2011). However, this response depends on the concentration of $\mathrm{P}$ and other competing elements in soil (Suriyagoda et al. 2018). As there is a risk of accumulating high concentrations of toxic trace elements in vegetables grown in the region, agronomic mitigation strategies need to be implemented in order to ensure the sustainability of these cropping systems and the health of consumers.

\section{Concluding Remarks}

Intensive vegetable cultivating lands in Nuwara Eliya and Welimada regions of Sri Lanka are owned by small-scale $(<0.5 \mathrm{ha})$ farmers. They apply heavy doses of agrochemicals to maximize their crop productivity per land per year. Due to this practice, soil nutrient and toxic trace element concentrations 
have been built up to high concentrations, risking the contamination of streams and groundwater through leaching and runoff. Three major vegetable crops grown in the region; cabbage, carrot and potato also contained high concentrations of mineral elements and toxic trace elements. However, the concentrations of $\mathrm{As}, \mathrm{Cd}$ and $\mathrm{Pb}$ did not exceed the maximum permissible limits. Improving the awareness of farmers on their malpractices, and the introduction of good agricultural practices (GAP) are urgently needed to conserve soil and ensure the sustainability of these cropping systems.

\section{Declarations}

\section{Declarations}

Authors declare no conflicts of interest.

\section{Acknowledgements}

The authors acknowledge the technical assistance given by the officers in the Department of Crop Science, Faculty of Agriculture, Mr. Anurashantha and Agriculture Instructors (AI) in the region for field assistance. Financial support was provided by the University of Peradeniya.

\section{References}

1. Abeywickrama HM, Koyama $Y$, Uchiyama M, Shimizu U, Iwasa $Y$, Yamada E, Ohashi K, Mitobe $Y$ (2018) Micronutrient status in Sri Lanka: A review. Nutrients 10:1583

2. Adams F, Burmester C, Hue NV, Long FL (1980) A comparison of column-displacement and centrifuge methods for obtaining soil solutions. Soil Sci Soc Am J 44:733-735

3. AgStat (2018) Agricultural Statistics. Department of Agriculture, Peradeniya, Sri Lanka

4. Akhtar S, Ismail T, Atukorala S, Arlappa N (2013) Micronutrient deficiencies in South Asia, Current status and strategies. Trends Food Sci Tech 31:55-62

5. Ali M, Tsou SCS (1997) Combating micronutrient deficiencies through vegetables-a neglected food frontier in Asia. Food Policy 22:17-38

6. Anderson JM, Ingram JSI (1993) Tropical Soil Biology and Fertility: A Handbook of Methods, 2nd edn. CAB International, Wallingford

7. Bandara JM, Wijewardena HV, Seneviratne HM (2010) Remediation of cadmium contaminated irrigation and drinking water: a large scale approach. Toxicol Lett 198:89-92

8. Bártová V, Diviš J, Bárta J, Brabcová A, Švajnerová M (2013) Variation of nitrogenous components in potato (Solanum tuberosum $\mathrm{L}$.) tubers produced under organic and conventional crop management. Eur J Agron 49:20-31

9. Dandeniya WS, Caucci S (2020) Composting in Sri Lanka: Policies, Practices, Challenges, and Emerging Concerns. In: Hettiarachchi H, Caucci S, Schwärzel K (eds) Organic Waste Composting 
through Nexus Thinking: Practices, Policies, and Trends. Springer International Publishing, Cham, pp 61-89

10. Dissanayake CB, Chandrajith R (2009) Phosphate mineral fertilizers, trace metals and human health. Journal of National Science Foundation Sri Lanka 37:153-165

11. Diyabalanage S, Samarakoon KK, Adikari SB, Hewawasam T (2017) Impact of soil and water conservation measures on soil erosion rate and sediment yields in a tropical watershed in the Central Highlands of Sri Lanka. Appl Geogr 79:103-114

12. Dizon F, Herforth A, Wang Z (2019) The cost of a nutritious diet in Afghanistan, Bangladesh, Pakistan, and Sri Lanka. Glob Food Secur 21:38-51

13. DOA (2003) Agro-Ecological Regions of Sri Lanka. State Printing Coorporation, Sri Lanka

14. Dobosy P, Endrédi A, Sandil S, Vetési V, Rékási M, Takács T, Záray G (2020) Biofortification of potato and carrot with iodine by applying different soils and irrigation with iodine-containing water. Front Plant Sci 11

15. EU (2006) Setting maximum levels for certain contaminants in foodstuffs', Official Journal of the European Union, 364(1881), pp. 5-24. Available at: https://ec.europa.eu/food/safety/chemical_safety/contaminants/legislation_en

16. FAO/WHO (2001) Human Vitamin and Mineral Requirements. Food and Agriculture Organization of the United Nations and World Health Organization, Rome

17. FAO/WHO (2019) CODEX Alimentarius, International Food Standards. Food and Agriculture Organization of the United Nations and World Health Organization, Rome

18. GAIN (2014) China's Maximum Levels for Contaminants in Foods. Global Agricultural Information Network, $\mathrm{CH} 14058$

19. General Soil Map (1967) Ceylon, General Soil Map. Survey Department Ceylon, Sri Lanka

20. Houba VJG, Temminghoff EJM, Gaikhorst GA, van Vark W (2000) Soil analysis procedures using $0.01 \mathrm{M}$ calcium chloride as extraction reagent. Commun Soil Sci Plan 31:1299-1396

21. IMNA (2001) Dietary Reference Intakes for. In: Vitamin A, Vitamin K, Arsenic Boron, Chromium, Copper, lodine, Iron, Manganese, Molybdenum, Nickel, Silicon, Vanadium, and Zinc. Institute of Medicine of The National Academies (IMNA), National Academies Press (US), Washington (DC)

22. Jayasumana C, Fonseka S, Fernando A, Jayalath K, Amarasinghe M, Siribaddana S, Gunatilake S, Paranagama P (2015) Phosphate fertilizer is a main source of arsenic in areas affected with chronic kidney disease of unknown etiology in Sri Lanka. SpringerPlus 4:90

23. Jayawardena R, Jeyakumar DT, Gamage M, Sooriyaarachchi P, Hills AP (2020) Fruit and vegetable consumption among South Asians: A systematic review and meta-analysis. Diabetes Metab Syndr 14:1791-1800

24. Ju XT, Kou CL, Christie P, Dou ZX, Zhang FS (2007) Changes in the soil environment from excessive application of fertilizers and manures to two contrasting intensive cropping systems on the North China Plain. Environ Pollut (Barking, Essex: 1987) 145:497-506 
25. Kananke T, Wansapala J, Gunaratne A (2014) Heavy metal contamination in green leafy vegetables collected from selected market sites of Piliyandala area, Colombo district, Sri Lanka. Am J Food Sci Tech 2:139-144

26. Kananke T, Wansapala J, Gunaratne A (2016) Assessment of heavy metals in Mukunuwenna (Alternanthera sessilis) collected from production and market sites in and around Colombo district, Sri Lanka. Procedia Food Sci 6:194-198

27. Kanungsukkasem U, Ng N, Van Minh H, Razzaque A, Ashraf A, Juvekar S, Masud Ahmed S, Huu Bich $T$ (2009) Fruit and vegetable consumption in rural adults population in INDEPTH HDSS sites in Asia. Global Health Action 2:1988

28. Khai NM, Ha PQ, Öborn I (2007) Nutrient flows in small-scale peri-urban vegetable farming systems in Southeast Asia-A case study in Hanoi. Agr Ecosyst Environ 122:192-202

29. Khan A, Khan S, Khan MA, Qamar Z, Waqas M (2015) The uptake and bioaccumulation of heavy metals by food plants, their effects on plants nutrients, and associated health risk: a review. Environ Sci Pollut Res Int 22:13772-13799

30. Kiziloglu FM, Turan M, Sahin U, Kuslu Y, Dursun A (2008) Effects of untreated and treated wastewater irrigation on some chemical properties of cauliflower (Brassica olerecea L. var. botrytis) and red cabbage (Brassica olerecea L. var. rubra) grown on calcareous soil in Turkey. Agr Water Manage 95:716-724

31. Kobierski M, Lemanowicz J, Wojewódzki P, Kondratowicz-Maciejewska K (2020) The effect of organic and conventional farming systems with different tillage on soil properties and enzymatic activity. Agronomy 10:1809

32. Liang K, Jiang Y, Nyiraneza J, Fuller K, Murnaghan D, Meng F-R (2019) Nitrogen dynamics and leaching potential under conventional and alternative potato rotations in Atlantic Canada. Field Crops Res 242:107603

33. Liyanage CE, Thabrew MI, Kuruppuarachchi DSP (2000) Nitrate pollution in ground water of Kalpitiya: an evaluation of the content of nitrates in the water and food items cultivated in the area. Journal of the National Science Foundation of Sri Lanka 28:101-112

34. Mapa RB (2020) The Soils of Sri Lanka. Springer Nature, Switzerland

35. Olsen S, Cole C, Watanabe F, Dean L (1954) Estimation of Available Phosphorus. In: Soils by Extraction with Sodium Bicarbonate. USDA Circular Nr 939. Office, Washington, D.C. US Gov. Print.

36. Parpia AS, L'Abbé M, Goldstein M, Arcand J, Magnuson B, Darling PB (2018) The impact of additives on the phosphorus, potassium, and sodium content of commonly consumed meat, poultry, and fish products among patients with chronic kidney disease. Journal of Renal Nutrition: The Official Journal of the Council on Renal Nutrition of the National Kidney Foundation 28:83-90

37. Pingali PL (2012) Green Revolution: Impacts, limits, and the path ahead. PNAS USA 109:1230212308

38. Premarathna HMPL, Hettiarachchi CM, Indraratne SP (2005) Accumulation of cadmium in intensive vegetable growing soils in the up country. Tropical Agricultural Research 17:93-103 
39. Qiu Q, Wang Y, Yang Z, Yuan J (2011) Effects of phosphorus supplied in soil on subcellular distribution and chemical forms of cadmium in two Chinese flowering cabbage (Brassica parachinensis L.) cultivars differing in cadmium accumulation. Food Chem Toxicol 49:2260-2267

40. Samarakoon SMM, Abeygunawardena P (1996) An economic assessment of on-site effects of soil erosion in potato lands in Nuwara Eliya district of Sri Lanka. J Sustain Agr 6:81-92

41. SAS Institute (1995) SAS/Stat User Guide, Vol 2, Version 6.1. SAS Institute, Carry, NY

42. Setiyo Y, Harsojuwono BA, Gunam IBW (2020) The concentration of heavy metals in the potato tubers of the basic seed groups examined by the variation of fertilizers, pesticides and the period of cultivation. AIMS Agriculture Food 5:882-895

43. Shahid M, Dumat C, Khalid S, Schreck E, Xiong T, Niazi NK (2017) Foliar heavy metal uptake, toxicity and detoxification in plants: A comparison of foliar and root metal uptake. J Hazard Mater 325:3658

44. Sharma A, Katnoria JK, Nagpal AK (2016) Heavy metals in vegetables: screening health risks involved in cultivation along wastewater drain and irrigating with wastewater. SpringerPlus 5:488

45. Sirisena D, Suriyagoda LDB (2018) Toward sustainable phosphorus management in Sri Lankan rice and vegetable-based cropping systems: A review. Agriculture Natural Resources 52:9-15

46. Somaweera KATN, Suriyagoda LDB, Sirisena DN, De Costa WAJM (2017) Growth, root adaptations, phosphorus and potassium nutrition of rice when grown under the co-limitations of phosphorus, potassium and moisture. J Plant Nutr 40:795-812

47. Suriyagoda LDB, Dittert K, Lambers $H$ (2018) Mechanism of arsenic uptake, translocation and plant resistance to accumulate arsenic in rice grains. Agr Ecosyst Environ 253:23-37

48. Tack FMG (2014) Trace elements in potato. Potato Res 57:311-325

49. Takahashi M, Yanai Y, Umeda H, Sasaki H (2018) Relationship between growth and N:P of cabbage (Brassica oleracea L., var. capitata) plug seedlings according to moisture content and nitrogen and phosphorus application after transplanting. Sci Hortic-Amsterdam 233:294-301

50. Van Ranst E, Verloo M, Demeyer A, Pauwels JM (1999) Manual for the Soil Chemistry and Fertility: Laboratory-Analytical Methods for Soils and Plants, Equipment, and Management of Consumables. University of Gent, Gent

51. Wang B, Xie Z, Chen J, Jiang J, Su Q (2008) Effects of field application of phosphate fertilizers on the availability and uptake of lead, zinc and cadmium by cabbage (Brassica chinensis L.) in a mining tailing contaminated soil. J Environ Sci 20:1109-1117

52. Weerakkody WAP, Mawalagedera SMMR (2020) Recent Developments in Vegetable Production Technologies in Sri Lanka. In: Marambe B, Weerahewa J, Dandeniya WS (eds) Agricultural Research for Sustainable Food Systems in Sri Lanka: Volume 1: A Historical Perspective. Springer Singapore, Singapore, pp 189-214

53. Wen G, Huang L, Zhang X, Hu Z (2019) Uptake of nutrients and heavy metals in struvite recovered from a mixed wastewater of human urine and municipal sewage by two vegetables in calcareous soil. Environ Technol Innovation 15:100384 
54. Wijewardena J (2000) Comparison of animal manure sources on potato and vegetable cultivation in the upcountry. Annual Symposium of the Department of Agriculture, Sri Lanka. 2:357-369

55. Wijewardena JDH, Amarasiri SL (1997) Long-term use of potassium fertilizer for vegetable crops in the upcountry intermediate zone. Journal of the National Science Foundation of Sri Lanka 25:59-68

56. Yang P, Chen H-J, Fan H-Y, Li Q-S, Gao Q, Wang D-S, Wang L-L, Zhou C, Zeng EY (2019) Phosphorus supply alters the root metabolism of Chinese flowering cabbage (Brassica campestris L. ssp. chinensis var. utilis Tsenet Lee) and the mobilization of Cd bound to lepidocrocite in soil. Environ Exp Bot 167:103827

\section{Figures}
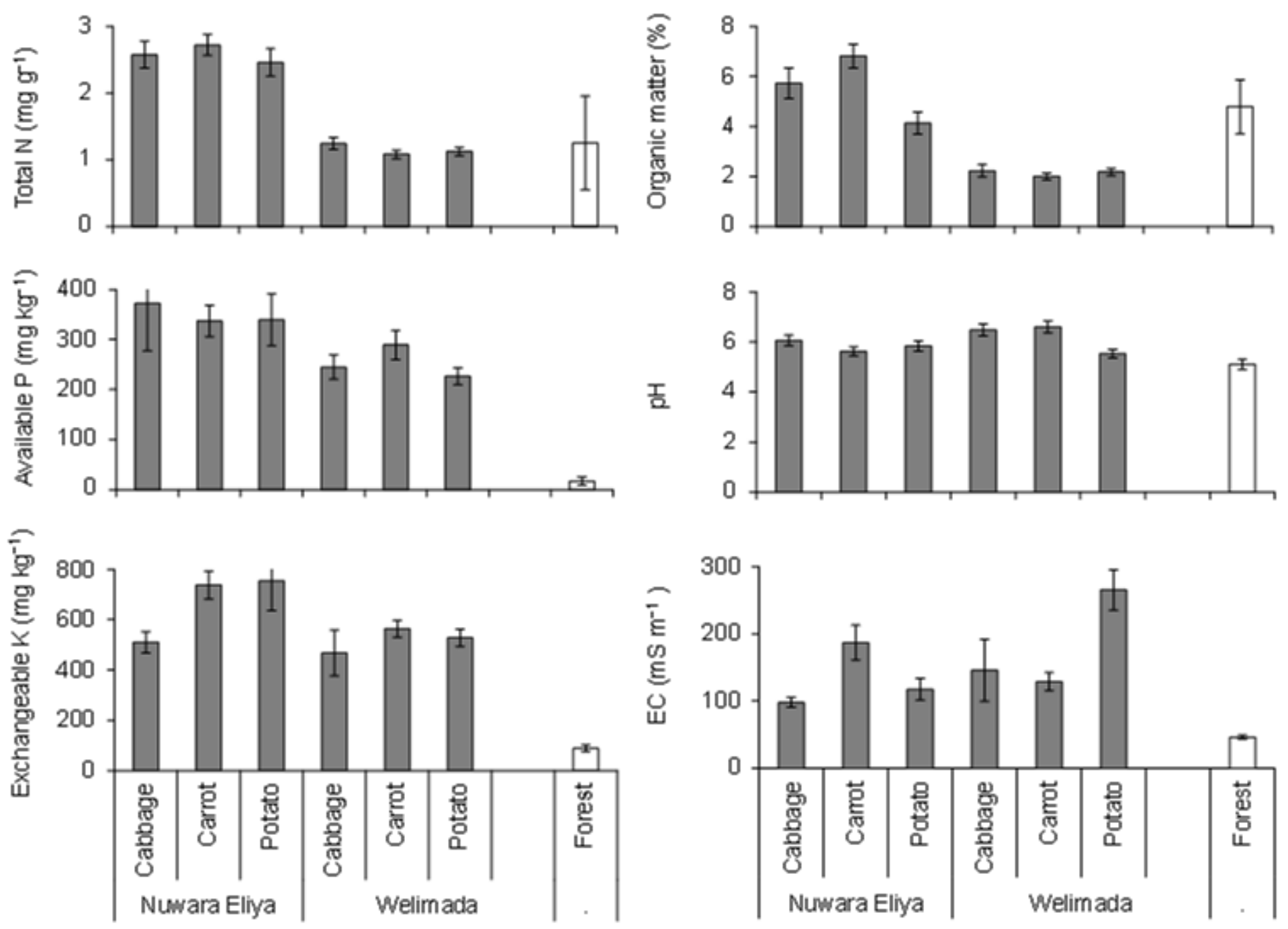

\section{Figure 1}

Concentrations of total nitrogen $(N)$, available phosphorus $(P)$, exchangeable potassium $(K)$, organic matter, $\mathrm{pH}$ and electrical conductivity in the crop and forest fields in the two study regions (mean $\pm \mathrm{SE}$, sample size is as stated in Table 2). 

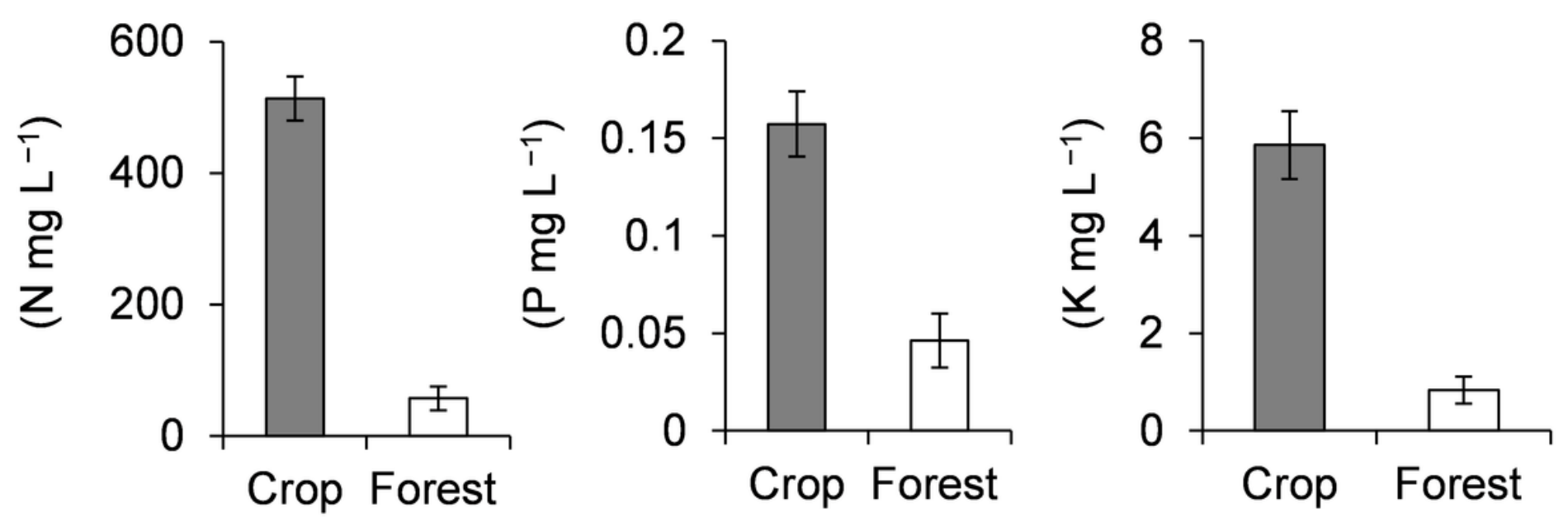

Figure 2

Concentrations of soil solution nitrogen $(\mathrm{N})$, phosphorus $(\mathrm{P})$ and potassium $(\mathrm{K})$ in the crop and forest fields (mean $\pm S E$, sample size is as stated in Table 2). 

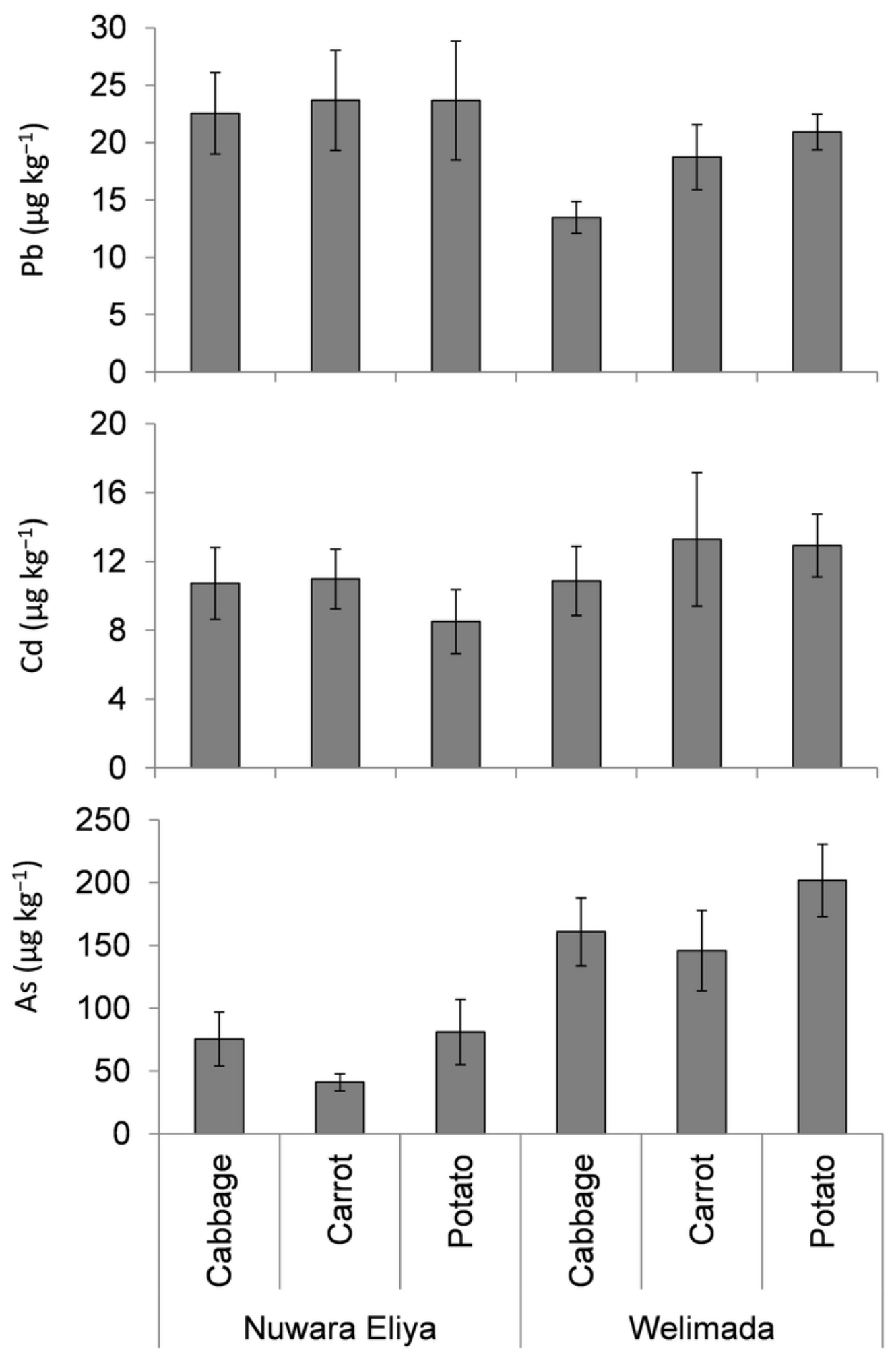

Figure 3

Concentrations of lead $(\mathrm{Pb})$, cadmium ( $\mathrm{Cd}$ ) and arsenic (As) in the crop fields from two cultivating regions (mean $\pm S E$, sample size is as stated in Table 2 ). 
Shoot
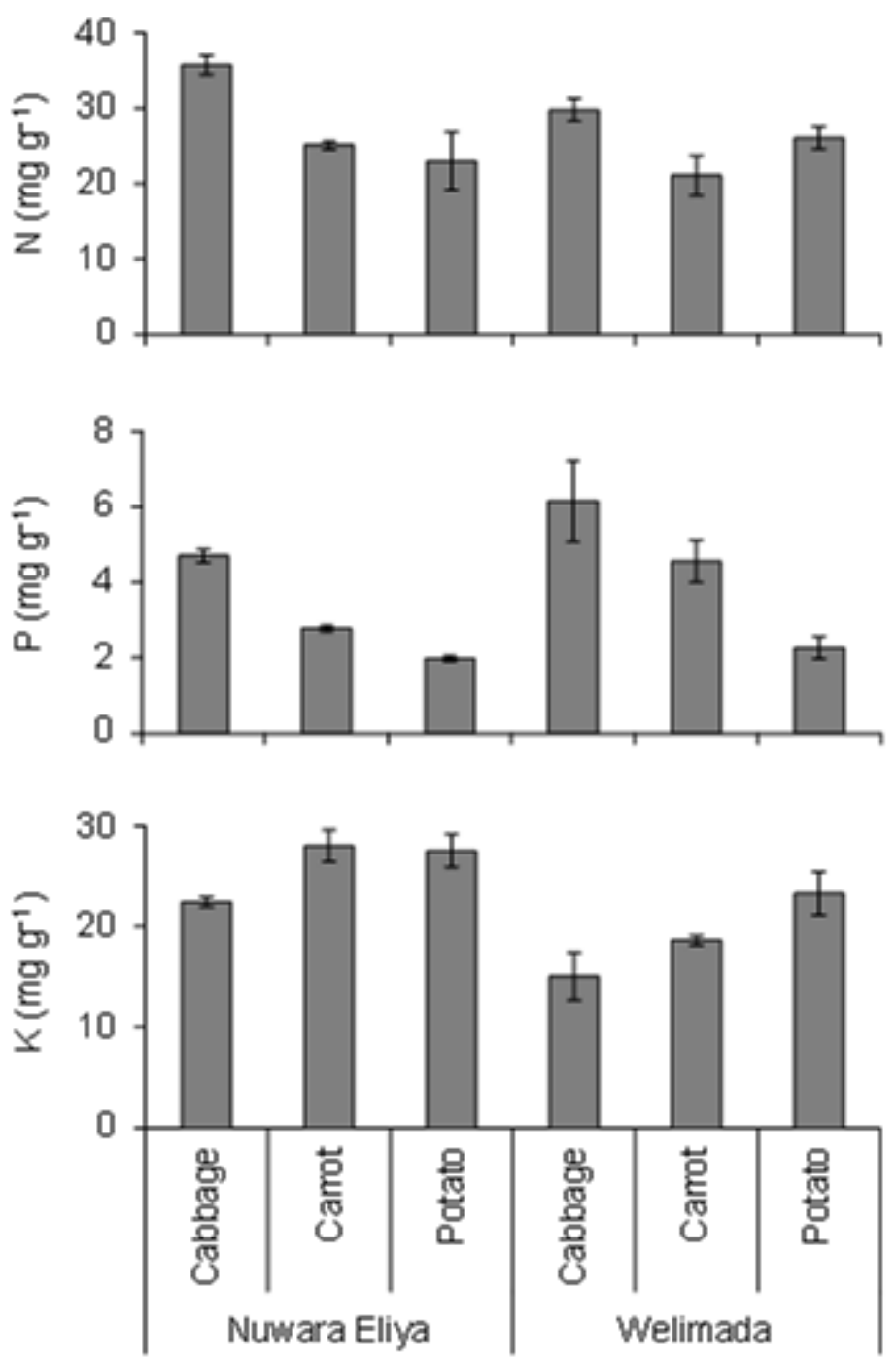

Root
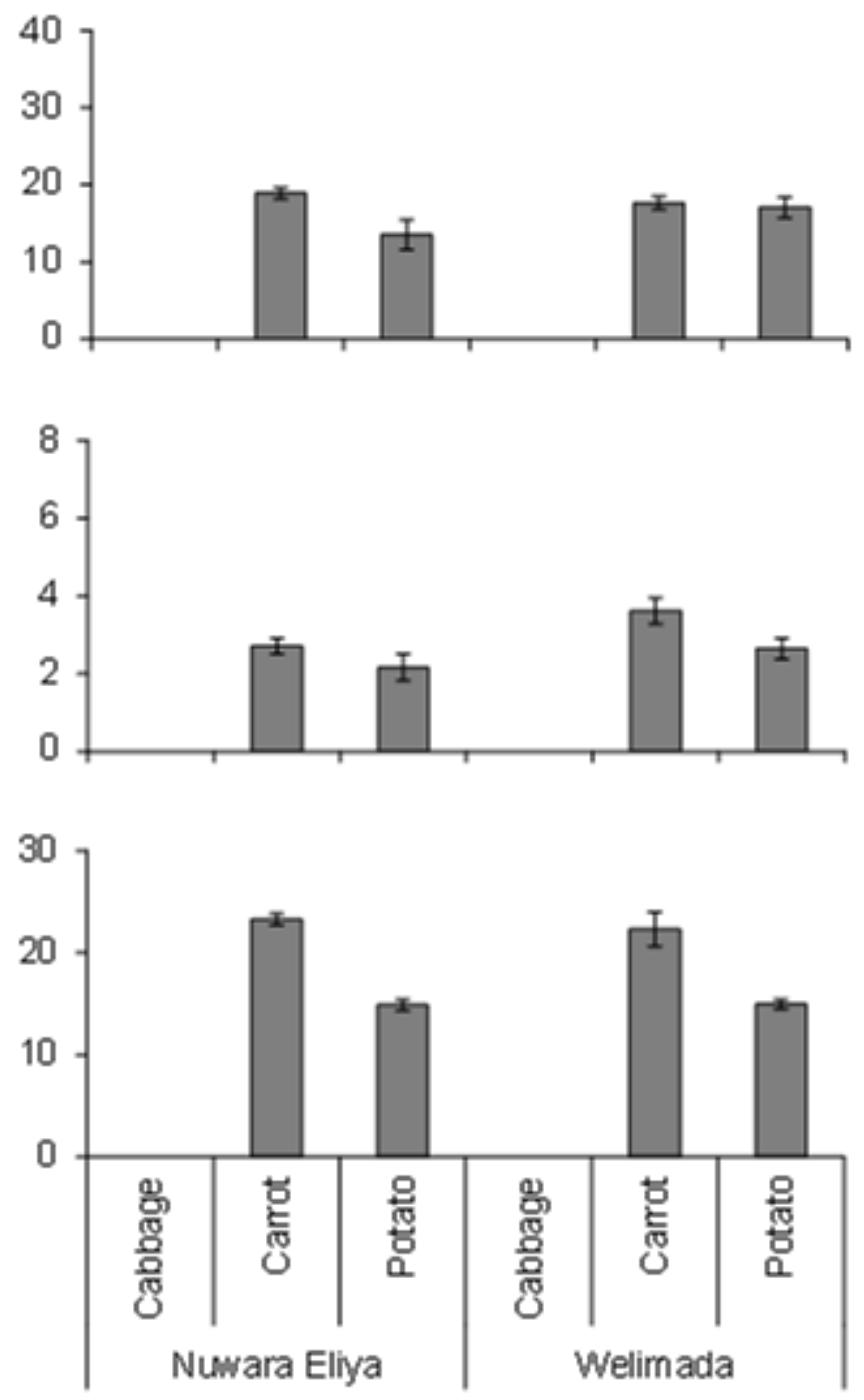

\section{Figure 4}

Tissue concentrations (on dry weight basis) of nitrogen $(P)$, phosphorus $(P)$ and potassium $(K)$ grown in the two regions (mean $\pm S E$, sample size is as stated in Table 2) 

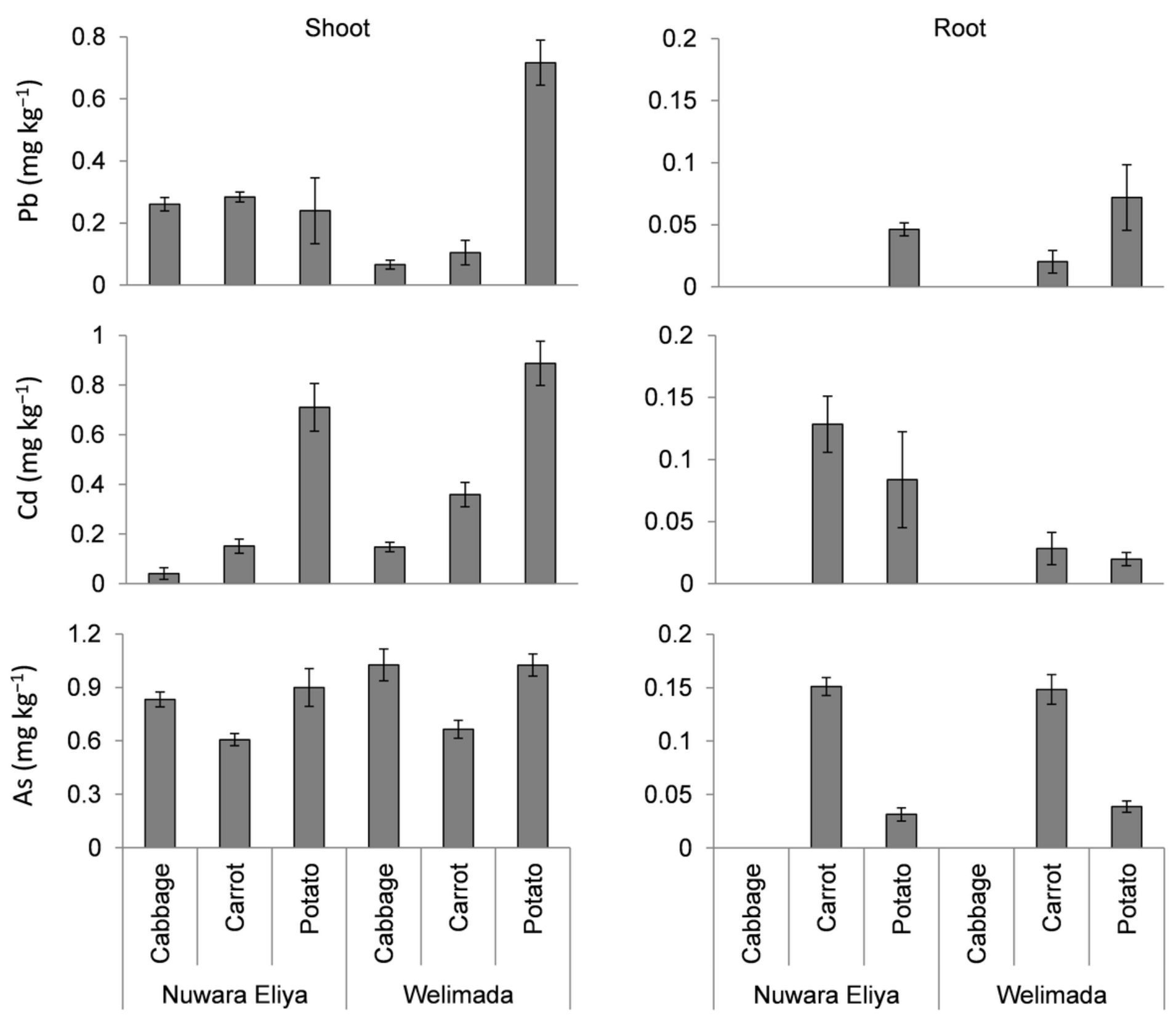

Figure 5

Tissue concentrations (on dry weight basis) of lead ( $\mathrm{Pb}$ ), cadmium (Cd) and arsenic (As) grown in two cultivating regions (mean $\pm S E$, sample size is as stated in Table 2). Note: the difference in $Y$-axis scale in the two panels. 

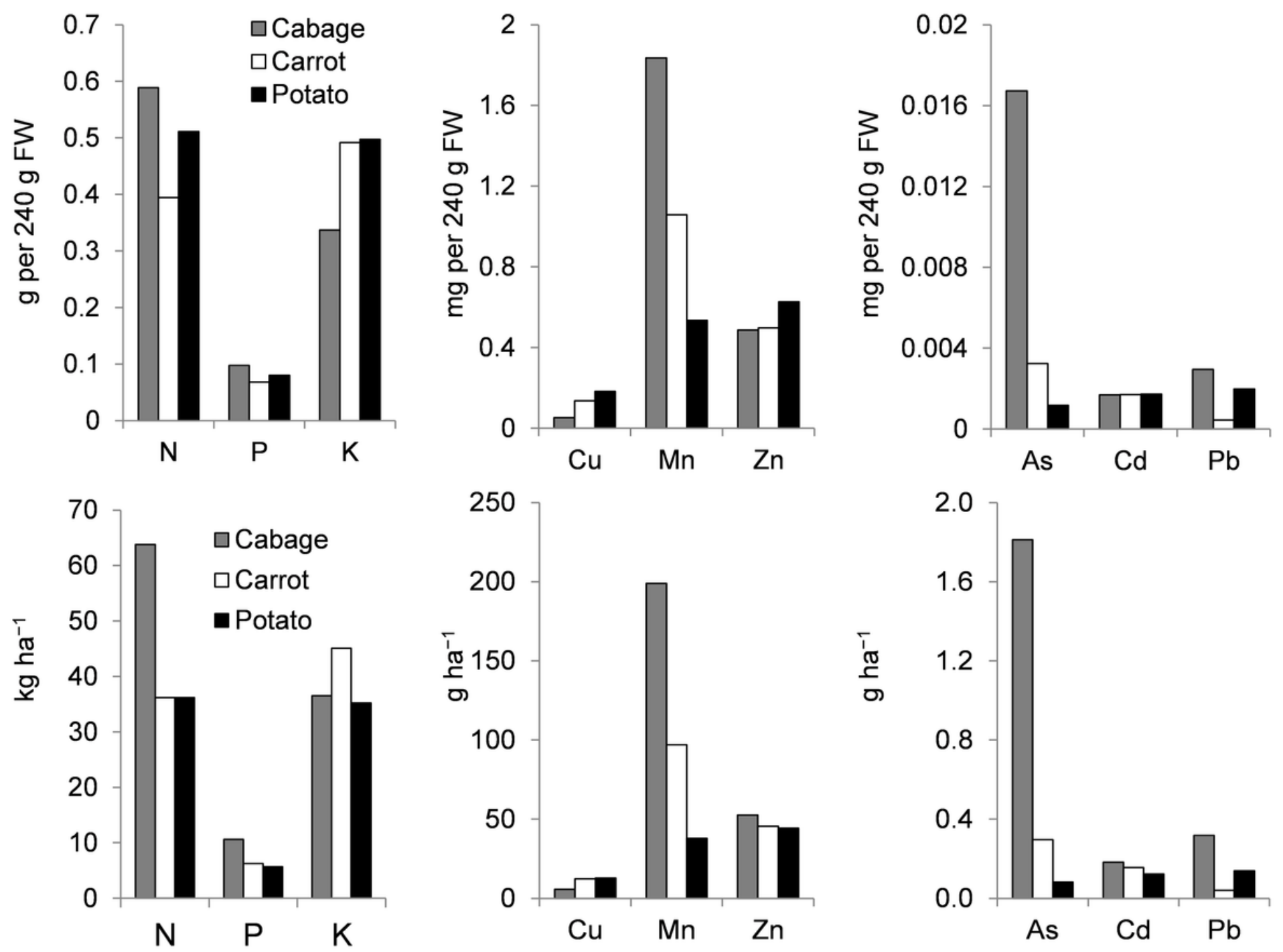

Figure 6

The mean amounts of essential mineral and toxic trace elements- present in $240 \mathrm{~g}$ (FW basis) of edible portion (upper panel), and removed with the harvest from one ha land (lower panel) of cabbage, carrot and potato. 